\title{
Articles
}

\section{Promoting Meaning and Life Satisfaction to Older Students through Service Learning in Continuing Education}

Maureen Reed and Marilyn Hadad, Ryerson University

\section{Abstract}

The objective of this study was to examine whether continuing education that focuses on service learning could provide older students (over the age of 50) with knowledge and skills that increase their life satisfaction, confidence, and community integration. We also examined whether it could provide them with meaningful and purposeful experiences. We surveyed older students prior to a service-learning program on satisfaction with life, self-esteem, extraversion, life purpose, depression, loneliness, and self-control coping. After completing the service-learning program, we again surveyed the older students, using the same measures one year later. We found that the service-learning program benefitted the students in terms of their self-esteem, loneliness, confidence, and skill

\section{Résumé}

L'objectif de cette étude est d'évaluer si la formation continue ciblant l'apprentissage par le service pouvait fournir aux étudiants plus âgés (51 ans et plus) des connaissances et des aptitudes qui améliorent leur satisfaction envers la vie, leur taux de confiance et leur intégration communautaire. Nous avons également étudié si la formation continue pouvait leur faire vivre des expériences utiles et enrichissantes. Nous avons sondé des étudiants plus âgés avant qu'ils n'entreprennent un programme d'apprentissage par le service. Nous les avons sondés sur leur satisfaction envers la vie, leur estime d'eux-mêmes, leur extraversion, leur raison d'être, la dépression, la solitude et la gestion de la maîtrise de soi. Un an plus tard, une fois le programme terminé, nous avons à nouveau sondé ces 
development. In addition, we learned that those who were less satisfied with their life prior to the service-learning program made the highest gains in life satisfaction following the service-learning program. We conclude that continuing education that focuses on service learning may be one way to provide older students with meaningful and psychologically beneficial social experiences. étudiants âgés à l'aide des mêmes mesures. Nous avons découvert que le programme d'apprentissage par le service avait eu un effet bénéfique sur ces étudiants quant à leur estime de soi, leur état de solitude, leur confiance et leur développement de compétences. En outre, nous avons appris que les gens qui étaient le moins satisfaits de leur vie avant d'entreprendre le programme d'apprentissage par le service avaient le plus progressé quant à leur niveau satisfaction dans la vie une fois le programme d'apprentissage par le service terminé. Nous concluons donc que la formation continue ciblant l'apprentissage par le service peut être une façon de permettre aux étudiants plus âgés de vivre des expériences sociales enrichissantes, qui leur soient bénéfiques psychologiquement.

Keywords: continuing education, life satisfaction, older students, self-esteem, service learning

\section{Introduction}

Older students, which we define as students over the age of 50, represent a significant and growing market in continuing education, and some researchers have shown there are benefits for older students who participate in continuing higher education (e.g., DiSilvestro, 2013). Furthermore, older students have expectations that the courses they take will be personally meaningful and beneficial (Swain \& Hammond, 2011). One way to meet their expectations may be to provide them with service-learning opportunities, that is, to learn through higher education courses while participating in organized service programs (e.g., assisting in hospitals, schools, non-profit organizations, long-term care). Our study examined the benefits to older students in a continuing-education service-learning program that prepared them to work in long-term care facilities as elder clowns. An elder clown is any individual of any age, who is trained to clown for vulnerable elderly long-term care residents. In elder-clown programs students are trained in aging theory and are taught how to encourage long-term care residents to communicate and interact through laughter, music, acting, and dance (Kontos, Miller, Mitchell, \& Stirling-Twist, 2015). Few studies have been conducted on the benefits to the older student of participating in such learning; however, Warren and Spitzer (2011) report 
that individuals who participate believe their work is important and rewarding. Examining the benefits to older students in participating in service learning through continuing education is the focus of this paper.

\section{Literature Review}

\section{Mature Students and Continuing Education}

Mature students (25+ years) studying in higher education, and typically through continuing education programs, represent a heterogeneous group and make up more than half of the population of part-time students in Canada and other countries (Association for Universities and Colleges in Canada [AUCC], 2011; Bill, 2013; Chen, J. C., 2014). Mature students over the age of 50 (called older students here) are one of the fastest growing markets in higher education, yet there has been little systematic research on this group (Cruce \& Hillman, 2012). Understanding the continuing-education experiences of these older students could result in positive impacts for colleges and universities, students and their communities.

Researchers have investigated why older students choose to attend continuing education programs. Swain and Hammond (2011) suggest that the reasons students arrive in higher education vary, depending on life circumstances. For example, older students less often attend to attain job-related skills (Cruce \& Hillman, 2012). McCune, Hounsell, Christie, Cree, and Tett (2010) and Swain and Hammond (2011) found that personal interest, social benefits, enjoyment, proving self-ability, and a desire to help others are often given as reasons to access continuing education.

\section{Benefits of Continuing Education for Older Students}

A few researchers have examined the benefits of continuing education for older students, though these studies are largely descriptive in nature (e.g., surveys). DiSilvestro (2013) found that older students feel that continuing education can promote a sense of community, skill development, and social interaction, but that these attributes only develop when consideration is given to the needs of the older student. In other words, as DiSilvestro points out, continuing education for the older student must hold value and promote personal meaning. Narushima (2008) observes that continuing education allows the older student to develop social networks and that these older students believe their education should be meaningful. Indeed, Hammond (2004) interviewed 145 students and reports that their education experience gave them confidence, self-understanding, a sense of purpose, and an ability to think. However, Hammond suggests that the type of education matters. J. C. Chen (2014) recommends that courses for older students should lead to personal development, include critical reflection, use personal life experience, and provide unique life-changing opportunities. 


\section{Student Benefits from Service Learning in Continuing Education}

One way to provide older students with meaningful opportunities is through service learning. Service learning is defined as learning through participation in organized service that is intended to meet a community need, and it is integrated into an academic program or training (Lewis, 2002). It typically involves the teaching of skills and theory, followed by the application of these skills and theory in a community setting (e.g., a practicum with a service organization). Lewis (2002) suggests that these courses enhance learning by joining theory with experience and are a way to get older adults to become more involved in community. In addition, Lewis argues, service-learning courses have the benefit of training volunteers for resource-restricted organizations, and they promote meaningful activity that has the potential to improve self-worth. Service learning also relates well to many of the reasons older students take courses in the first place (e.g., social benefits, enjoyment, proving self-ability, desire to help others).

Another benefit of continuing education service-learning programs is that they lead to volunteerism (defined here as service activities that are not course or program requirements), following completion of the service-learning program, something that has been shown to assist older adults in general. L. M. Chen (2013) suggests older adults who volunteer have reduced isolation and increased opportunities to contribute to the social fabric. Further, the review by Anderson et al. (2014) of 73 studies showed volunteerism in older adults is associated with reduced depression, better health, improved cognitive activity, improved psychosocial performance (e.g., self-esteem, life satisfaction), and fewer functional limitations. Yet, Celdran and Villar (2007) found that the satisfaction older adults have with volunteering and the setbacks they encounter when volunteering depend on the type of volunteer activity, with higher benefits and fewer drawbacks occurring when volunteering involves assisting vulnerable others. Given the benefits reported for volunteerism and for continuing education, service learning is an attractive opportunity to tie volunteerism and education together for older students, yet little is known about their combined impact on the student. This impact is the focus of this paper.

\section{Research Aims and Questions}

The aim of our research was to investigate the characteristics of older students who participate in and complete service learning, and examine the benefits of service learning for the older student. Our research asked the following questions:

- What are the characteristics of older students choosing and completing continuing education service learning, relative to those who do not complete?

- Are pre-program psychosocial scores unique for those who participate in service learning? 
- Do those older adults who join service-learning programs differ in their psychosocial characteristics relative to other older adults?

- Does participation in the service-learning program lead to psychosocial gains?

- Do older students who show lower psychosocial scores prior to service learning benefit more from the service-learning experience?

- Do older students with the strongest sense of well-being at the beginning of service learning have the strongest sense of well-being at the end?

- What do older students feel they offer and receive from their participation in service learning?

\section{The Study}

\section{Participants}

Participants included 25 older students ranging in age from 48 to 84 years $(M=61.5$ years, $S D=8.9$ ) who registered in the first of two courses in a continuing education service-learning program. Of these, only eighteen individuals (C group) completed the service-learning program, which included two courses (Introduction to Clowning and Elder Clown Basics) and a 17-hour practicum in a long-term care facility. Seven students (DNC group) did not continue in the service-program after the Introduction to Clowning course. These seven completed all study measures prior their Introduction to Clowning course, and their data was used as a comparator with those who chose to complete service learning (see Tables 1 and 2). The majority of students in both groups $(n=22)$ were female.

\section{Measures}

Past studies, cited in the introduction, show that continuing education alone and volunteering in the absence of education both lead to some positive personal benefits in terms of confidence, sense of purpose, self-understanding, reduction of depression, self-esteem, and life satisfaction (Anderson et al., 2014; Chen, C. J., 2014; Lewis, 2002). In addition, as cited in the introduction, older students may enrol in higher education to satisfy social reasons (gain friends, become more outgoing, reduce loneliness), to prove self-ability to meet challenges (self-control coping), and to foster a desire to learn to help others (McCune et al., 2010; Swain \& Hammond, 2011). Service-learning programs contain both continuing education and a practicum with service organizations (which may mimic the benefits of volunteering). The service-learning program at Ryerson University allowed older students to participate in continuing education to gain knowledge of aging and clowning skills, meet and socialize with peers, learn problem-solving strategies, reflect on the application of skills, and participate in a practicum in a long-term setting with vulnerable individuals. We believed that this combination could lead to positive personal benefits for students and fulfil the reasons that lead older adults to enrol in continuing 
education. Based on this, we chose measures that would reflect the students'sense of life satisfaction, self-esteem, extraversion, depression, life purpose, loneliness, and self-control coping. The scales chosen were all well established and accepted psychosocial measures and have been evaluated for reliability and validity.

\section{Demographic survey}

The survey developed by the researchers included 9 questions:

1. age

2. gender

3. highest level of education

4. current volunteer activities

5. current social clubs

6. frequency of social engagements

7. occupation

8. reason for joining the clown program

9. experience with dramatic arts

\section{Satisfaction with Life Scale (SWLS)}

The SWLS measure requires participants to rate, on a 7-point Likert scale (7 means strongly agree), five statements related to their satisfaction with life (e.g., "In most ways my life is close to my ideal") (Diener, Emmons, Larsen, \& Griffin, 1985). Item scores are summed and can vary from 5 to 35, with higher scores representing more satisfaction with life. Typically, older adult samples show means of about 24 to 26 with standard deviations around 7.5 (Diener et al, 1985; Pavot, Diener, Colvin, \& Sandvic, 1991; Rosengren, Jonasson, Brogardh, \& Lexell, 2015). Deiner et al. (1985) showed that the scale has internal consistency when used with geriatric samples and Pavot et al. (1991) found the scale correlates well with other measures of life satisfaction. Rosengren et al. (2015) reported retest reliability of 0.78 and Cronbach's alpha to be 0.9 .

\section{Rosenberg Self-Esteem}

This scale is a widely used 10-item scale measuring individuals' general feelings about themselves (global self-esteem) (Rosenberg, 1965). Scores on this scale range from 0 to 30, with higher values representing higher self-esteem. Typical values for older adult populations are between 23 and 25, with a standard deviation between 4 and 5 (Sinclair et al., 2010). This widely used scale has good convergent and discriminant validity and internal consistency (Cronbach's alpha between 0.84 and 0.91 for older adult populations) (Sinclair et al., 2010). In addition, it correlates well with other measures of well-being (Sarvimaki \& Stenbock-Hult, 2000). 


\section{Eysenck's Personality Questionnaire Revised-Short (EPQ-S)}

This questionnaire measures extraversion/introversion using a 12-item scale (EPQ-S; Eysenck, Eysenck, \& Barrett, 1985; Francis, Lewis, \& Zeibertz, 2006). Scores on this scale vary from 0 to 12 , with higher scores representing a more extraverted personality. A typical score for the general population and for older adults is about 6.6 (SD = 3.8) (Barrett \& Eysenck, 1992; Parslow, Jorm, Christensen, Rodgers, \& Jacomb, 2005). Francis et al. (2006) reported that the scale has high internal consistency (Cronbach's alpha of 0.85) and Francis, Craig, and Robbins (2008) found it was consistent with other measures of extraversion.

\section{Geriatric Depression Scale-Short Form (GDS)}

The GDS-Short Form measures depression in older adult samples (Sheikh \& Yesavage, 1986). This 15-item scale uses yes/no questions about affect (e.g., "Do you feel happy most of the time?") and behaviours (e.g., "Have you dropped many of your activities and interests?"). Scores range from 0 to 15, with higher scores representing greater levels of depression. Marc, Raue, and Bruce (2008) report internal consistency of 0.80. Arthur, Jagger, Lindesay, Graham, and Clarke (1999) showed the scale has high sensitivity and specificity in detecting depression in older adult populations and reported median scale values of 2 with an interquartile range of 1 to 3 .

\section{General Life Purpose Scale}

This scale measures participants' sense of their general life purpose (Byron \& Miller-Perrin, 2009). Scores range from 15 to 105, with higher scores representing higher life purpose. Byron and Miller-Perrin reported the scale correlates with other measures of life purpose with internal consistency of 0.91. Typical scores range between 78 and 86 with standard deviations around 12 (Byron \& Miller-Perrin, 2009; Howell, Passmore, \& Buro, 2013).

\section{UCLA Loneliness Scale-Version 3}

This scale measures levels of loneliness (Russell, 1996). Scores can vary from 20 to 80 with higher scores representing higher levels of loneliness. Typical scores for middle-aged to elderly samples are between 32 and 45 (SD = 7-14) (Russell, 1996; Tse, Wong, \& Wan 2012; Vijayshri \& Farooqi, 2014). Russell found the scale has internal consistency (Cronbach's alpha $=0.89$ ), with older adult populations, test-retest reliability of 0.73 and is well correlated with other measures of loneliness.

\section{Self-Control Schedule (SCS)}

This schedule is a 36-item scale that assesses general learned-resourcefulness/self-control coping skills (Rosenbaum, 1980). The scale assesses the level at which individuals, when faced with stressful situations, use problem-solving strategies ("When I feel that I am too impulsive, I tell myself to stop and think before I do anything"), delay gratification ("I prefer to finish a job that I have to do before I start doing things I really like."), manage self-change ("When I try to get rid of a bad habit, I first try to find out all the reasons why I have the habit"), and use positive 
self-statements ("When an unpleasant thought is bothering me, I try to think about something pleasant"). Total scores can range from -108 to +108 , with higher scores indicating higher resourcefulness. The scale has internal consistency (Cronbach's alpha $=0.78)$ and correlates with other measures of resourcefulness (Zauszniewski, Lai, \& Tithiphontumrong, 2006). Mean scores for older adult populations range between 30 to 33 and standard deviations range from 18 to 20 (Rosswurm, Larabee, \& Zhang, 2002).

\section{Follow-up Questionnaire}

The researchers developed a follow-up questionnaire that included open-ended emailed questions about whether participants were still elder clowns, whether they felt the program made a difference for residents, whether or not the program made a difference to them, how their service learning affected other aspects of their life, and whether they believe they received (or did not receive) benefits by becoming an elder clown.

\section{Procedures}

All participants were enrolled in a service-learning program offered through a continuing education unit at Ryerson University in Canada. The service-learning program consisted of two courses (Introduction to Clowning, 12 hours; Caring/Elder Clown Basics, 21 hours); a practicum at long-term care homes where participants practised their skills under supervision (17 hours). Within the program, participants also studied topics related to aging and how to communicate and work with older adults with dementia. They were also taught clowning skills and methods in order to engage with individuals in long-term care and were encouraged to reflect on their learning and experiences. Approval to undertake research with human subjects was obtained by the Ryerson University Institutional Ethics Review Board.

After ethical approval, participants took part in pre-program and post-program measures over a period of one year, either in person or by mail. The pre-program session was conducted prior to or within the first two weeks of beginning the Introduction to Clowning course, and the post-program session took place five to six months after completion of the practicum. During each in-person session, participants read and signed a consent form, followed by completion of the demographic survey (pre-program only) and the seven psychosocial measures described above. Mail-out participants received the same consent forms and identical instructions, but these were in a written format, and consent forms and questionnaires were returned via mail. A follow up-questionnaire was emailed to all C participants a minimum of five months after the post-program session and was returned by email. 


\section{Data Analysis}

To examine characteristics of individuals entering the service-learning program, descriptive statistics were used. Seven individuals began the service-learning program but left after the first course. We wondered if differences existed between students who chose to leave and those who chose to stay. Tests of differences (t-tests) were used to compare demographic and psychosocial responses between those who did and did not continue. We also compared initial pre-program measures for all psychosocial measures with scores published for similar populations, using 95\% confidence to determine if there is something unique about those who chose to enter a service-learning program. For those who completed the service-learning program, dependent $t$ comparisons were used to compare the psychosocial scores before and after the program, to determine if the service-learning program led to psychosocial changes. In order to determine whether those scoring the lowest at pre-program on psychosocial measures had higher psychosocial gains (as suggested by Piliavin and Siegl, 2007) from participation in service learning, we correlated a gain score (pre-program measures-post-program measures) with the pre-program measures. Correlation was also used to determine if those with the strongest sense of well-being at the beginning of the service-learning program had the strongest at the end. A content analysis by theme was conducted on the follow-up survey.

\section{Results}

Results of participant responses to our questionnaires were aggregated and they are summarized below for each research question.

\section{What are the characteristics of older students choosing and completing continuing education service learning, relative to those who do not complete?}

Eighteen older students completed the service-learning program, while seven left the program following the first course. We wondered if there were characteristics that distinguish students who complete or do not complete a service-learning program through continuing education.

Generally, participants were highly educated and had previously participated in drama (Table 1). Forty-four percent had previous volunteer experience and $48 \%$ belonged to a social club. There were no demographic differences between the $C$ and DNC participants, except that those in the DNC group more often had professional drama experience. Previous or current occupations of participants most often included social work (28\%), business (34\%), and teaching (28\%). Two individuals stated they were artists, and one individual did not report an occupation. Participants stated that they joined the elder-clown program because they wanted to try something that would be fun or different, or that they liked the concept of helping in long-term care. 
Table 1: Demographic Responses of People Choosing to Study Clowning and Caring Clown.

\begin{tabular}{|c|c|c|c|c|c|}
\hline \multirow[b]{2}{*}{ Age } & \multicolumn{2}{|c|}{$\begin{array}{r}\text { Complete (C) } \\
\text { Mean (SD) } \\
N=18\end{array}$} & \multicolumn{2}{|c|}{$\begin{array}{r}\text { Did Not Continue } \\
\text { (DNC) Mean (SD) } \\
\mathbf{N}=7\end{array}$} & \multirow{2}{*}{$\begin{array}{c}\text { Significance } \\
p=0.83\end{array}$} \\
\hline & 61.72 & $(9.65)$ & 60.86 & $(7.24)$ & \\
\hline Number of volunteer hours / week & 1.89 & $(2.74)$ & 0.93 & $(1.34)$ & $p=0.39$ \\
\hline Attend social club hours / week & 2.22 & $(2.98)$ & 2.71 & $(2.75)$ & $p=0.71$ \\
\hline $\begin{array}{l}\text { Frequency visiting family / friends } \\
\text { (times / week) }\end{array}$ & 2.47 & $(1.63)$ & 4.0 & $(2.92)$ & $p=0.23$ \\
\hline Percent with higher education & & $83.3 \%$ & & $71.4 \%$ & $p=0.64$ \\
\hline Percent with drama experience & & $77.8 \%$ & & $85.7 \%$ & $p=0.656$ \\
\hline $\begin{array}{l}\text { Percent with professional drama } \\
\text { experience }\end{array}$ & & $21.4 \%$ & & $83.3 \%$ & $p=0.032^{*}$ \\
\hline Percent live alone & & $33.3 \%$ & & $28.5 \%$ & $p=0.83$ \\
\hline
\end{tabular}

* Significant

Do those older adults who join service-learning programs differ in their psychosocial characteristics relative to other older adults?

Pre-program (baseline) psychosocial measures are reported in Table 2. Overall, C group shows no differences in psychosocial values on measures, prior to the program, from the DNC group. Nor does either group differ from values expected in literature from older participants, based on confidence.

Table 2: Psychosocial Measures at Baseline for Caring Clowns and Do Not Continue, Relative to Typical Outcomes from Literature.

\begin{tabular}{|c|c|c|c|c|c|c|}
\hline \multirow[b]{2}{*}{ The Satisfaction with Life Scale } & \multicolumn{2}{|c|}{$\begin{array}{r}\text { Complete }(C) \\
\text { Mean(SD) } \\
N=18\end{array}$} & \multicolumn{2}{|c|}{$\begin{array}{r}\text { Did Not Continue } \\
\text { (DNC) Mean (SD) } \\
N=7\end{array}$} & \multicolumn{2}{|c|}{$\begin{array}{l}\text { Reported scores } \\
\text { in literature }\end{array}$} \\
\hline & 25.44 & $(6.66)$ & 28.71 & $(4.46)$ & $24-26$ & $(7.5)$ \\
\hline Rosenberg Self-Esteem Scale & 21.61 & $(4.57)$ & 25.00 & $(4.90)$ & $23-25$ & $(4-5)$ \\
\hline $\begin{array}{l}\text { Eysenck's Personality } \\
\text { Questionnaire-Extraversion }\end{array}$ & 7.22 & $(3.20)$ & 5.29 & $(4.31)$ & 6.6 & $(3.8)$ \\
\hline Geriatric Depression Scale* & $1^{*}$ & $(2.00)$ & 0.00 & $(2.00)^{*}$ & $M d n=2$ & $(2)^{*}$ \\
\hline The General Life Purpose Scale & 74.28 & $(7.84)$ & 77.57 & $(5.68)$ & 78-86 & $(12)$ \\
\hline UCLA Loneliness Scale & 41.83 & $(9.02)$ & 39.86 & (12.13) & $32-45$ & $(7-14)$ \\
\hline Self-Control Schedule & 28.39 & $(23.06)$ & 44.14 & $(27.62)$ & $30-33$ & $(18-20)$ \\
\hline
\end{tabular}

* Medians and interquartile ranges as is typical in literature 


\section{Does participation in the service learning program lead to psychosocial gains?}

The act of training and volunteering as an elder clown had some psychosocial benefits to the C group (Table 3). Small but significant increases in self-esteem ( $t_{16}=-2.67, p=0.02$; Cohen's $d=-0.65)$, and small but significant decreases in loneliness were found $\left(t_{16}=2.54, p=0.02\right.$; Cohen's $d=0.62$ ) between pre- and post-program.

Table 3: Comparison between Pre- and Post Service-Learning Psychosocial Measures.

\begin{tabular}{lccccc} 
& & $\begin{array}{r}\text { Pre-Service } \\
\text { Learning } \\
\text { Mean (SD) }\end{array}$ & $\begin{array}{r}\text { Post-Service } \\
\text { Learning } \\
\text { Mean (SD) }\end{array}$ & $\begin{array}{r}\text { Significance } \\
\text { Based on } \\
\text { dependent t } \\
\text { comparisons }\end{array}$ \\
$\begin{array}{l}\text { Satisfaction with Life Scale } \\
\text { Rosenberg Self-Esteem Scale }\end{array}$ & 25.7 & $(6.81)$ & 27.2 & $(5.24)$ & $p=0.13$ \\
Eysenck's Personality & 21.47 & $(4.67)$ & 22.94 & $(4.21)$ & $p=0.02$ \\
Questionnaire-Extraversion & 7.06 & $(3.27)$ & 7.41 & $(3.78)$ & $p=0.27$ \\
Geriatric Depression Scale & 1.41 & $(1.5)$ & 0.94 & $(1.39)$ & $p=0.27$ \\
General Life Purpose Scale & 74.35 & $(8.07)$ & 73.88 & $(8.04)$ & $p=0.76$ \\
UCLA Loneliness Scale & 42.47 & $(8.87)$ & 38.31 & $(8.93)$ & $p=0.02$ \\
Self-Control Schedule & 27.71 & $(23.58)$ & 24.59 & $(24.71)$ & $p=0.55$ \\
\hline
\end{tabular}

\section{Do older students who show lower psychosocial scores prior to service learning benefit more from the service-learning program?}

Some researchers suggest that those who score low on psychosocial measures benefit the most from volunteering (Piliavin \& Siegl, 2007). Psychosocial gains were correlated with pre-program scores for all psychosocial measures for participants who completed the service-learning program. Overall, those who initially scored lower in life satisfaction made greater gains in satisfaction than did those who initially scored higher in life satisfaction $(r=-.64, p=$ 0.006). These results were not due to ceiling effects. Except for one participant who scored at ceiling (highest value on satisfaction) on both the pre- and post-program for life satisfaction, none of the participants hit ceiling on their post-program measures. Data were re-analyzed for the group without the one individual who had ceiling on pre- and post-program measures and the outcome was identical $(r=0.65, p=0.006)$. Further, those who showed the highest pre-program depression scores made larger reductions in depression than did those who had lower initial depression scores. $(r=-629, p=0.007$ ). Six participants scored at ceiling (no depression) on the depression index for pre-program measures. Given that these participants could not improve, they were removed from the sample and the analysis was re-run. However, the outcome was the same $(r=-.7, p=0.016)$. 


\section{Do older students with the strongest sense of well-being at the beginning of the service-learning program have the strongest sense of well-being at the end?}

Moderate to high correlations were found between pre-program psychosocial values and post-program values ranging from $r=0.62$ to 0.95 (all $p<0.05$ ), except for geriatric depression, where no significant correlations in depression scores were found between pre- and post-program. Generally, those with the highest psychosocial performance at pre-program maintained high performance relative to those with lower psychosocial performance. The lack of depression pre- and post-correlation shows that all C participants had little depression.

There were significant correlations between psychosocial variables at both pre-program and post-program that are detailed in Table 4.

Table 4: Correlations between Pre- and Post-program Psychosocial Variables.

\begin{tabular}{|c|c|c|c|c|c|c|}
\hline $\begin{array}{c}\text { Psychosocial } \\
\text { variable }\end{array}$ & Pre-servi & earning | & ogram & Post-service & earning & rogram \\
\hline Life Satisfaction & Self Control & $r=0.55$ & $p=0.02$ & Self-esteem & $r=0.61$ & $p=0.01$ \\
\hline & & & & Life Purpose & $r=0.48$ & $p=0.05$ \\
\hline & & & & Loneliness & $r=-.52$ & $p=0.04$ \\
\hline Self-esteem & Extraversion & $r=0.54$ & $p=0.02$ & Extraversion & $r=0.64$ & $p=0.01$ \\
\hline & Life purpose & $r=0.55$ & $p=0.02$ & Life purpose & $r=0.55$ & $p=0.02$ \\
\hline & Loneliness & $r=-.49$ & $p=0.04$ & Loneliness & $r=-.65$ & $p=0.004$ \\
\hline & Depression & $r=-.50$ & $p=0.04$ & Life satisfaction & $r=0.61$ & $p=0.01$ \\
\hline Extraversion & Self-esteem & $r=0.54$ & $p=0.02$ & Self-esteem & $r=0.64$ & $p=0.01$ \\
\hline & Life purpose & $r=0.5$ & $p=0.04$ & Loneliness & $r=-.61$ & $p=0.01$ \\
\hline & Loneliness & $r=-.58$ & $p=0.01$ & & & \\
\hline & Depression & $r=-.56$ & $p=0.02$ & & & \\
\hline Depression & Self-esteem & $r=-.5$ & $p=0.04$ & No associations & & \\
\hline & Extraversion & $r=-.56$ & $p=0.02$ & & & \\
\hline & Life purpose & $r=-.73$ & $p=0.001$ & & & \\
\hline & Loneliness & $r=.73$ & $p=0.001$ & & & \\
\hline & Self Control & $r=-.49$ & $p=0.04$ & & & \\
\hline Life Purpose & Self-esteem & $r=0.55$ & $p=0.02$ & Self-esteem & $r=0.55$ & $p=0.02$ \\
\hline & Extraversion & $r=0.50$ & $p=0.04$ & Life satisfaction & $r=0.48$ & $p=0.05$ \\
\hline & Depression & $r=-.73$ & $p=0.001$ & & & \\
\hline
\end{tabular}




\begin{tabular}{l|lrc|llll}
\multicolumn{1}{c}{$\begin{array}{c}\text { Psychosocial } \\
\text { variable }\end{array}$} & \multicolumn{2}{c}{ Pre-service learning program } & \multicolumn{2}{c}{ Post-service learning program } \\
\hline Loneliness & Self-esteem & $r=-.49$ & $p=0.04$ & Self-esteem & $r=-.52$ & $p=0.03$ \\
& Extraversion & $r=-.58$ & $p=0.01$ & Extraversion & $r=-.61$ & $p=0.01$ \\
& Depression & $r=.73$ & $p=.001$ & Life Satisfaction & $r=-.65$ & $p=0.004$ \\
\hline Self-Control & Life Satisfaction & $r=.55$ & $p=.02$ & No associations & & \\
Coping & Depression & $r=-.49$ & $p=0.04$ & & & \\
\hline
\end{tabular}

Life Satisfaction. At pre-program, those with higher life satisfaction showed higher self-control coping; however, at post-program those with the highest life satisfaction also had the highest self-esteem, life purpose, and the least loneliness.

- Self-esteem. Those with the highest self-esteem at pre-program also showed the highest levels of extraversion and life purpose, and the lowest levels of loneliness and depression. At post-program, those with the highest self-esteem continued to be the most extraverted, have the highest life purpose, and were less lonely; however, self-esteem no longer predicted depression but did predict life satisfaction.

- Extraversion. At pre-program, those with the highest levels of extraversion also showed the highest levels of self-esteem and life purpose, and the lowest levels of loneliness and depression. However, at post-program extraversion was only associated positively with self-esteem and negatively with loneliness.

- Depression. At pre-program those with the highest levels of depression had the lowest levels of self-esteem, life purpose, extraversion, and self-control coping, and the highest levels of loneliness. At post-program, depression scores were not associated with any other variables.

- Life Purpose. Life purpose was associated positively with self-esteem and extraversion, and negatively with depression, but in post-program those with the highest life purpose also had the highest self-esteem and life satisfaction.

- Loneliness. Loneliness was negatively associated with self-esteem and extraversion, and positively associated with depression at pre-program. At post-program those with the highest levels of loneliness had the lowest self-esteem, extraversion, and life satisfaction.

- Self-Control Coping. Those with the highest self-control coping also had higher life satisfaction and less depression at pre-program. At the end of the study self-control coping was not associated with other psychosocial variables. 


\section{What do older students feel they offer and receive from their participation in service learning?}

Eleven of the 17 C participants (65\%) responded to an email survey. Nine were still active in their trained service, one stated that he/she will resume service involvement, and one indicated that he/she had given up service in long-term care for personal reasons.

Students were asked how elder clowning made a difference to the residents they interact with. They spoke about residents' engagement: smiling, laughing, singing, and dancing. One student observed: "They are very happy when we arrive and quite often don't want us to leave. We get very positive feedback not only from the staff but also from the families of residents."

Several older students said it was difficult to measure the meaning to the residents. One stated, "Staff tell us that residents are happier, less tense when we have been there. When told that the clowns are coming, residents show anticipation."

Several students believed their impact was in the moment, but important. As one shared:

Residents have joined in an old song that may have triggered a memory, bringing a smile or sometimes a tear to their eyes. Laughter at silly antics that we engage in makes us know that they are "Still Alice," just trapped in an unforgiving disease.

We asked if participating in the program made a difference to the student. Seven answered that this service learning allowed them to better understand aging and its challenges. Viewing those challenges pushed them to try to be more empathetic and understanding. One stated, "This program has certainly made me become more aware of others' needs. I realize how people like to be listened to and validated."

Students were asked if participating helped them in other areas of life. Among their responses they said this service learning

- helped them feel confident,

- helped them make friends,

- allowed them to better understand aging,

- helped them to feel happy and playful,

- helped them to try new skills,

- allowed them to practise acting skills, and

- made them self-reflective.

As one student said,

It taught me that I am capable of picking up new skills that were completely new and beyond any expectation, given my basic personality - it seems to be possible for me to grow, despite my advanced age. 
Students were asked about difficulties they experienced in service learning. A few mentioned that they were nervous about moving beyond their comfort zone when interacting with longterm care residents. A few found it hard to deal with some of the negative aspects of aging (e.g., dementia and death).

\section{Discussion}

The experience of service learning through continuing education benefited older students in terms of their self-esteem, loneliness, confidence, and skill development. Further, those who were less satisfied with their life and had higher negative affects made higher positive gains through their continuing education. The experience also resulted in changes in factors related to life satisfaction, life purpose, depression, and self-control.

Older students' profiles, prior to participating in service learning in this study, are not very different from other older adults who volunteer (but not as part of an education program). Researchers suggest that older adults who volunteer have positive psychosocial profiles (Gasiorek \& Giles, 2013). Here, we find that the students, prior to their continuing education and whether or not they completed the program, scored within normative ranges on all psychosocial measures, were generally already socially active in their communities, and had attained higher education.

What was unique to this sample was the high number with drama experience. This is not surprising, given that they were training in elder clowning, a highly dramatic field. The commitment to a year's training and using acting to reach vulnerable others may be of more interest to those who are familiar with drama and educational acquisition. Regardless, one unforeseen aspect was that some students described learning and service challenged them to self-reflect upon their own attitudes and social interactions. Such reflection may be one of the benefits to service learning for older students and may also be a catalyst for self-change following service learning.

Continuing education service learning resulted in some benefits, including increases in self-esteem and decreases in loneliness. Also, students stated that the program promoted social interactions and increased their skill levels and confidence. Further, those with less life satisfaction and more depression made the greatest gains in these areas after completing the service-learning program. In service learning, education is combined with service activities. Here learning about aging, elder clowning, and long-term care was combined with clowning for vulnerable others. Part of service learning is self-reflection, that is, attaching theory taught in courses to service activities and reflecting on this combination.

In our follow-up questionnaire, older students in this study reported personal growth as a result of participation and a feeling that the service they were doing was meaningful (see results). While there are many possible reasons why our older students showed benefits 
between pre- and post-program measures, we speculate that benefits we find are due, in part, to students' educational experience of service learning. Gasiorek and Giles (2013) suggest that the belief that one is contributing may result in positive health outcomes. Members of our sample initially stated that they joined our service-training program for fun and to work with vulnerable others. After their education and their practicum, they suggested that their work in long-term care mattered to them and the vulnerable residents. It may be that the meaning found through the reflective practice used in service learning is what leads to the personal benefits we found in this study. This is consistent with the overall finding in positive psychology that people who feel they have meaning in their lives report greater life satisfaction than those who do not (Hadad, 2013).

Associations between psychosocial variables were dynamic over the course of the study. Given that the participants were training in a new skill, learning about aging, interacting with other participants and residents, creating new social groups, and reflecting on their own contributions, it is not surprising that changes would occur. These dynamic associations likely reflect changes in perspectives that occur with continuing education as presented through the service-learning program. Specifically, the service-learning program offered students skills and opportunities to engage in meaningful activity, which could change their perspective by giving students a sense of purpose and increased awareness of their own abilities and new skills.

Here, we found that life satisfaction became associated with life purpose and self-esteem, and depression and self-control coping was no longer associated with other study measures. At the same time the engagement required in this service-learning program appeared to change the feelings of negative affect, perhaps allowing students to dissociate it from purpose and self-esteem (e.g., making it context specific). On the other hand, our positive outcomes may be associated with students who have high theoretical and skills training and have high commitment and engagement. Thus, while we find benefits here, it is still unclear whether other forms of service learning might lead to similar benefits (e.g., training that results in less-direct assistance of the vulnerable).

Rosenbaum (1980) defines self-control coping as the ability to problem solve, delay gratification in order to reach a higher goal, make positive self-statements when confronted with stressful challenges, and recognize the efforts it takes for self-change. Surprisingly, students did not increase their resourcefulness, based on Rosenbaum's Self-Control Schedule, even though service learning promotes planning, goal direction, positive views, and effort. Furthermore, self-esteem was no longer a predictor of learned resourcefulness by the end of the study, but it had increased over the program of the study. It may be that service programs attract students who already are generally resourceful, and simply learning to apply these skills to a new context may have resulted in the increase in self-esteem. 


\section{Limitations}

One limitation of this study was that students acted as their own control with a pre-programpost-program model. This was done because of the inherent heterogeneity of older students in terms of continuing education experiences, making it hard to find a comparable group. Yet, it would be desirable to compare the benefits of different types of service-learning activities for older students. This will be the focus of a future study. A second limitation of our study is our small sample size. The service-learning program studied was a small-size program, in part due to the need for feedback in skills training and the need to provide placements in longterm care facilities. As a result, the sample size in our study is only eighteen individuals and thus results should be viewed with caution. For example, while we did find that the psychosocial profiles of this sample were similar to other older adults, it is possible that those who choose service learning through higher education are in some ways unique. Perhaps students who are already looking for meaningful service opportunities are more likely to seek out these educational opportunities. As such, it is difficult to fully generalize these results beyond older adults who express interest in service. However, understanding characteristics of older adults who would most likely enrol in service learning could assist higher education institutions in program development.

\section{Conclusions}

The current study provides evidence that service learning through continuing education leads to psychosocial benefits for older students. Specifically, older students who completed service learning had positive changes in life satisfaction, life purpose, self-esteem, and loneliness. Another positive outcome was that the students came to believe that the service they were doing was important, with many continuing this service after the program ended.

We believe the benefits that we found for older students in the service-learning program highlight the assistance service-learning models provide in creating an atmosphere where older adults can learn new skills and find meaning through supporting vulnerable others. Because the older students desire to work with vulnerable others was given as a reason for participation in continuing education, placing knowledgeable older students in long-term care facilities gave strong validation to the service-learning program.

As such, service learning might attract a growing market of older students to higher education. However, in the current study, older students studied and worked with vulnerable others. Whether similar findings would occur for service learning in other fields (e.g., fundraising) has yet to be determined. 


\section{Acknowledgments}

The authors received funding for this project from the Vice-Provost Academic, Ryerson University. Thanks also for the advice given by Lynda Del Grande, who taught elder clown, and Sandra Kerr, from Ryerson's Programs for 50+.

\section{References}

Anderson, N. D., Damianakis, T., Kröger, E., Wagner, L. M., Dawson, D. R., Binns, M. A., Bernstein, S., Caspi, E., Cook, S.L., \& BRAVO Team. (2014). The benefits associated with volunteering among seniors: A cr itical review and recommendations for future research. Psychological Bulletin, 140(6), 1505-1533. doi: 10.1037/a0037610

Arthur, A., Jagger, C., Lindesay, J., Graham, C., \& Clarke, M. (1999). Using an annual over-75 health check to screen for depression: Validation of the short geriatric depression scale (gds15) within general practice. International Journal of Geriatric Psychiatry, 14, 431-439.

Association for Universities and Colleges in Canada (AUCC) (2011). Trends in higher education: Volume 1 [enrollment]. Retrieved April 1, 2016 from http://www.univcan.ca/ media-room/publications/trends-in-higher-education-enrolment/

Barrett, P. T. \& Eysenck, S. B. G. (1992). Predicting EPQR full scale scores from the short form version. Personality and Individual differences, 13(7), 851-853.

Bill, C. (2013). We can do more to support mature students. Adults Learning, Winter, 14-15.

Byron, K., \& Miller-Perrin, C. (2009). The value of life purpose: Purpose as a mediator of faith and well-being. The Journal of Positive Psychology, 4(1), 64-70.

doi: 10.1080/17439760802357867

Celdran, M., \& Villar, F. (2007) Volunteering among older Spanish adults: Does the type of organization matter? Educational Gerontology, 33, 237-251. doi: 10.1080/03601270601161181

Chen, J. C. (2014). Teaching non-traditional adult students: Adult learning theories in practice. Teaching in Higher Education, 19(4), 406-418. doi: 10.1080/13562517.2013.860101

Chen, L. M. (2013). Senior volunteerism in Japan: A policy perspective. Ageing International 38, 97-107. doi: 10.1007/s12126-012-9168-x

Cruce, T. M., \& Hillman, N. W. (2012). Preparing for the silver tsunami: The demand for higher education among older adults. Research in Higher Education, 53, 593-613.

doi: 10.1007/s11162-011-9249-9

Diener, E., Emmons, R. A., Larsen, R. J., \& Griffin, S. (1985). The satisfaction with life scale. Journal of Personality Assessment, 49, 71-75. 
DiSilvestro, F. R. (2013). Continuing higher education and older adults. A growing challenge and golden opportunity. New Directions for Adult and Continuing Education, 140, 79-87. doi: 10.1002/ace.20076

Eysenck, S. B. G., Eysenck, H. J., \& Barrett, P. (1985). A revised version of the psychoticism scale. Personality and Individual Differences, 6, 21-29.

Francis, L. J., Craig, C. L., \& Robbins, M. (2008). The relationship between the Keirsey Temperament Sorter and the short-form Revised Eysenck Personality Questionnaire. Journal of Individual Differences, 29(2), 116-120. doi: 10.1027/1614-0001.29.2.116

Francis, L. J., Lewis, C. A., \& Ziebertz, H. G. (2006). The short-form revised Eysenck personality questionnaire (EPQ-S): A German edition. Social Behavior and Personality, 34(2), 197-204.

Gasiorek, J., \& Giles, H. (2013). Communication, volunteering, and aging: A research agenda. International Journal of Communication, 7, 2659-2677.

Hadad, M. (2013). The satisfying life: Positive psychology and personal growth. Toronto, ON: Pearson.

Hammond, C. (2004). Impacts of lifelong learning upon emotional resilience, psychological and mental health: Fieldwork evidence. Oxford Review of Education, 30(4), 551-568. doi: 10.1080/0305498042000303008

Howell, A. J., Passmore, H. A., \& Buro, K. (2013). Meaning in nature: Meaning in life as a mediator of the relationship between nature connectedness and well-being. Journal of Happiness Studies, 14, 1681-1696. doi: 10.1007/s10902-012-9403-x

Kontos, P., Miller, K. L., Mitchell, G. J., \& Stirling-Twist, J. (2015). Presence redefined: The reciprocal nature of engagement between elder-clowns and persons with dementia. Dementia, 2015. doi: 10.1177/1471301215580895

Lewis, M. (2002). Service learning and older adults, Educational Gerontology, 28(8), 655-667, doi: $10.1080 / 03601270290081461$

Marc, L. G., Raue, P. J., \& Bruce, M. L. (2008). Screening performance of the geriatric depression scale (GDS-15) in a diverse elderly home care population. American Journal of Geriatric Psychiatry, 16(11), 914-921. doi:10.1097/JGP.0b013e318186bd67

McCune, V., Hounsell, J., Christie, H., Cree V. E., \& Tett, L. (2010). Mature and younger students' reasons for making the transition from further education into higher education. Teaching in Higher Education, 15(6), 691-702. doi: 10.1080/13562517.2010.507303

Narushima, M. (2008). More than nickels and dimes: The health benefits of a community-based lifelong learning programme for older adults. International Journal of Lifelong Education, 27(6), 673-692. doi: 10.1080/02601370802408332

Parslow, R. A., Jorm, A. F., Christensen, H., Rodgers, G., \& Jacomb, P. (2005). Pet ownership and health in older adults: Findings from a survey of 2,551 community-based Australians aged 60-64. Gerontology, 51(1), 40-47. doi: 10.1159/000081433 
Pavot, W., Diener, E., Colvin C., \& Sandvik, E. (1991). Further validation of the satisfaction with life scale: Evidence for the cross-method convergence of well-being measures. Journal of Personality Assessment, 51(7), 149-161.

Piliavin, J. A., \& Siegl, E. (2007). Health benefits of volunteering in the Wisconsin longitudinal study. Journal of Health and Social Behavior, 48(4), 450-464.

Rosenbaum, M. (1980). A schedule for assessing self-control behaviors: Preliminary findings. Behavior Therapy, 11, 109-121.

Rosenberg M. (1965). Society and the adolescent self-image. Princeton: Princeton University Press.

Rosengren L., Jonasson S. B., Brogardh C., \& Lexell J. (2015). Psychometric properties of the satisfaction with life scale in Parkinson's disease. Acta Neurologica Scandinavica, 132, 164-170. doi: 10.1111/ane.12380

Rosswurm, M, A., Larabee, J. H., \& Zhang, J. (2002). Training family caregivers of dependent elderly adults through on-site and telecommunications programs. Journal of Gerontological Nursing, 28(7), 27-38.

Russell, D. W. (1996). UCLA Loneliness Scale (Version 3): Reliability, validity, and factor structure. Journal of Personality Assessment, 66(1), 20-40.

Sarvimaki, A., \& Stenbock-Hult B. (2000). Quality of life in old age described as a sense of well-being, meaning and value. Journal of Advanced Nursing 32(4), 1025-1033.

Sheikh J. I., \& Yesavage, A. (1986). Geriatric depression scale (GDS): Recent evidence and development of a shorter version. In T. L. Brink (Ed.) Clinical gerontology: A guide to assessment and intervention (pp. 165-173). New York: Haworth.

Sinclair, S. J., Blais, M. A., Gansler, D. A., Sandberg, E., Bistis, K., \& LoCicero, A. (2010). Psychometric properties of the Rosenberg self-esteem scale: Overall and across demographic groups living within the United States. Evaluation \& the Health Professions, 33(1), 56-80. doi: $10.1177 / 0163278709356187$

Swain J., \& Hammond, C. (2011). The motivations and outcomes of studying for part-time mature students in higher education. International Journal of Lifelong Education, 30(5), 591-612. doi: 10.1080/02601370.2011.579736

Tse, M. M. Y., Wong, A. M. H. \& Wan, V. T. C. (2012). Happiness among community-dwelling older persons: Is it related to pain and loneliness? Journal of Pain Management, 5(2), 163-175.

Vijayshri, \& Farooqi, F. S. (2014). Relationship of feelings of loneliness and depression symptoms in old age: A study of older adults living with family and living alone. Indian Journal of Health and Wellbeing, 5(12), 1428-1433.

Warren, B., \& Spitzer, P. (2011). Laughing to longevity-The work of elder clowns. The Lancet, 378, 562-563.

Zauszniewski, J. A., Lai, C. Y., \& Tithiphontumrong, S. (2006). Development and testing of the resourcefulness scale for older adults. Journal of Nursing Measurement, 14(1), 57-68. 


\section{Corresponding Author}

Maureen Reed PhD

Department of Psychology

Ryerson University

350 Victoria St.

Toronto, ON M5B 2K3

Email mreed@psych.ryerson.ca

\section{Biography}

Maureen Reed is an associate professor in psychology at Ryerson University, Toronto. Her research areas include visual perception, human development, aging plasticity, perceptual changes in aging, aging and driving, and disabilities.

Maureen Reed est professeure agrégée en psychologie à I'Université Ryerson, à Toronto. Ses recherches portent sur la perception visuelle, le développement humain, la plasticité vieillissante, les changements de perception du vieillissement, le vieillissement et la conduite automobile, ainsi que les déficiences.

Marilyn Hadad is Associate Professor Emeritus in psychology at Ryerson University. She is the author of several textbooks including The Satisfying Life: Positive Psychology and Personal Growth. Her research interest is on how human beings create a meaningful life.

Marilyn Hadad est professeure agrégée émérite en psychologie à I'Université Ryerson. Elle a écrit plusieurs livres dont The Satisfying Life: Positive Psychology and Personal Growth. Ses recherches portent sur les moyens qu'entreprend l'être humain pour se créer une vie enrichissante. 